\title{
Pioneer in Happiness Research in Latin America
}

\section{Mariano Rojas ${ }^{1}$}

Received: 1 July 2019 / Accepted: 1 September 2019/Published online: 20 November 2019

(C) The International Society for Quality-of-Life Studies (ISQOLS) and Springer Nature B.V. 2019

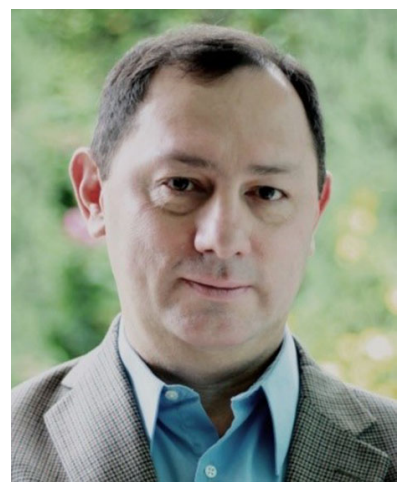

I consider myself a social scientist who is interested in human happiness; whatever is relevant to people's happiness attracts my attention. I understand happiness as a living experience human beings have rather than as an academic construct.

I studied economics at the University of Costa Rica as well as at The Ohio State University. As expected, my economics studies orbited around the topics of income and economic growth. I was always skeptical about the uncorroborated assumption that income is a good proxy for people's well-being and that utility - a term that in economics is usually associated to well-being- was not observable.

There are two important moments that have marked my research career. First, in 1998, I started working with own surveys to study happiness in Mexico. I was expecting income to be a major driver of people's happiness, but its explanatory power was very low. Many of my economics colleagues rejected this finding; their advice was to abandon this line of research and to distrust people's self-reports. Fortunately, I had the opportunity of participating at an ISQOLS conference in 2000; it was in ISQOLS where I found a large group of researchers from many disciplines interested in studying happiness. Over the years I have attended many ISQOLS conferences, ISQOLS

Mariano Rojas

mariano.rojas.h@gmail.com

1 UNIR, Spain, and UPAEP, Mexico, Puebla, Mexico 
researchers have become my highly esteemed friends, and ISQOLS has become my academic home; I even had the privilege of serving ISQOLS as its President.

Looking for an explanation to the low explanatory power of income, I found myself exploring the domains-of-life approach. I realized that the happiness report is made by persons while economists work with consumers; economics has confused consumers with persons, and purchasing power with well-being. Empirical research clearly shows that there is more to life than income, and that for many people there are more important aspects in life (Rojas 2007). This also allowed me to better understand those persons who report high happiness levels, although score poorly on commonly-used objective measures of quality of life, like income (Rojas 2008). It is not that they are contempt with small mercies -as some scholars argue-; it is that the conceptualization and measurement of poverty is very limited in capturing all the relevant factors that intervene in a person's happiness. This has led to a critique of how poverty is conceptualized as well of poverty-abatement programs that get obsessed with increasing people's income while neglecting many other relevant aspects in their life (Rojas 2015).

A second moment in my research career came when worldwide surveys became widely available and it was found that Latin Americans report high life-satisfaction levels. High happiness in Latin America did not correspond to the situation portrayed by the economic and social indicators which are commonly used by the international community. Quick explanations such as the 'cultural bias' and the 'fool's paradise' arguments emerged. It was, in the end, a similar reaction to the one I had faced before: if the report does not correspond to the predominant view then there is something wrong with the report -or perhaps with people themselves-. I realized that most socioeconomic indicators conflicting with people's reports rely on expert-views approaches. Hence, I started pondering on the foundations of the theoretical frameworks behind the construction of top-down constructed well-being indices as well as on the many biases that experts introduce when their views, values and interests prevail over those of people all over the world. I believe that happiness reports are very useful to escape from the many deficiencies of top-down approaches and that the job of an expert is not to judge other people's lives but to understand their own judgment (Rojas 2015).

My recent research focuses on understanding the high happiness levels that Latin Americans report. Our research shows that Latin America is abundant in high-quality human relations and that this is an important driver of happiness (Rojas 2018). I am focusing on relations that are inherently gratifying, either in an affective or evaluative way. The social capital literature has emphasized civic and instrumental relations, but I am more interested in person-based interpersonal relations. It is not about being polite but about being warm, genuinely interested and really caring for each other. It is person-based relations which are abundant in Latin America; they take place in the family and extended family areas, and also with friends, coworkers and neighbors (Rojas 2020). Person-based interpersonal relations are not about expecting support from others but about the joint enjoyment of life. The welfare state and the market system can provide close substitutes to the supportive role of interpersonal relations, but they are very inefficient as substitutes to the joint enjoyment that comes from person-based interpersonal relations.

I think that a better understanding of Latin Americans' happiness can be useful to the global discussion on social progress, modernization processes, environmentally 
friendly development, the notion of wealth, and the role of emotions and positive affect in well-being studies. I strongly believe that our understanding of human happiness benefits a lot from having research from all corners of the world.

\section{References}

Rojas, M. (2007). The complexity of well-being: A life-satisfaction conception and a domains-of-life approach. In I. Gough \& A. McGregor (Eds.), Researching Well-Being in Developing Countries: From Theory to Research (pp. 259-280). Cambridge: Cambridge University Press.

Rojas, M. (2008). Experienced poverty and income poverty in Mexico: A subjective well-being approach. World Development, 36(6), 1078-1093.

Rojas, M. (2015). Poverty and People's well-being. In W. Glatzer, V. Moller, L. Camfield, \& M. Rojas (Eds.), Global Handbook of Quality of Life (pp. 317-350). New York: Springer.

Rojas, M. (2018). Happiness in Latin America has social foundations. In J. Helliwell, R. Layard, \& J. Sachs (Eds.), World Happiness Report 2018. New York: Sustainable Development Solutions Network.

Rojas, M. (2020) Well-Being in Latin America: Drivers and Policies, Springer.

Publisher's Note Springer Nature remains neutral with regard to jurisdictional claims in published maps and institutional affiliations. 